\title{
Ultrastructural demonstration of retrovirus antigens with immuno-gold staining in prodromal acquired immune deficiency syndrome
}

\author{
WW FEREMANS, ${ }^{*}$ R MENU,${ }^{*}$ M GOLDMAN,$\dagger$ L SCHANDENE,$\dagger$ D PORTETELLE,$\ddagger$ \\ Y CLEUTER,$\ddagger$ J FLAMENT,$\dagger$ P DUSTIN,${ }^{*} \mathrm{~J}$ WYBRAN,$\dagger$ A BURNY $\ddagger$
}

From the *Laboratory of Pathology and Electron Microscopy, tthe Cliniques Universitaires de Bruxelles, Hopital Erasme, and łthe Institute of Molecular Biology, Rhode-St-Genèse, Université Libre de Bruxelles, Belgium

SUMMARY The peripheral lymphocytes of a patient with prodromal acquired immune deficiency syndrome contained giant multivesicular bodies. These were specifically stained by immuno-gold labelled polyclonal antibodies against the major core protein p24 of bovine leukaemia virus and human T cell leukaemia virus I. Moreover, the patient's serum was positive for bovine leukaemia virus by the ELISA method.

It is increasingly likely that the transmissible causative agent of acquired immune deficiency syndrome (AIDS) is a variety of $\mathrm{T}$ lymphotropic retrovirus. Vilmer et $\mathrm{l}^{1}$ have isolated a lymphadenopathic virus from two siblings with haemophilia, one of whom had AIDS. Popovic et $a l^{2}$ have developed a cell system for the reproducible detection of human $T$ cell leukaemia virus III from patients with AIDS and pre-AIDS.

Ultrastructural immunological staining has recently progressed with the use of colloidal goldantibody probes. ${ }^{3}$ We report the observations made with this technique on the peripheral lymphocytes from a prodromal case of AIDS using a panel of polyclonal and monoclonal antibodies directed against different retrovirus antigens.

\section{Case report}

A 56 year old Zairean woman was admitted for severe weight loss, diffuse lymph node enlargement, and slight fever. She denied any sexual contact for four years and had not received any transfusions or immunosuppressive treatment. She had not been outside Europe for 20 years. Haematological data showed moderate lymphopenia $\left(2.5 \times 10^{9} / 1\right)$ and a loss of lymphocytes bearing the helper-inducer phenotype $(3 \%)$ as defined by the monoclonal OKT4 antibody (OKT4:OKT8 ratio $0 \cdot 04$ ). $\mathrm{Cu}-$ taneous anergy for a panel of five antigens was noted. All in vitro measurements of $\mathrm{T}$ lymphocyte function were decreased, including mitogenic responses to phytohaemagglutinin, concanavalin $\mathrm{A}$, candidin, $\gamma$-interferon production, and interleukin 2 production. Natural killer cell activity using K562 cells as targets was considerably decreased. Immunoglobulin concentrations were raised: IgG 73 g/l, IgA 3.15 g/l, Ig M 4.63 g/l. Extensive investigation showed no lymphoproliferative neoplasia or other immunosuppressive diseases. Lymph node biopsy showed follicular hyperplasia similar to that reported in AIDS. IgG antibodies against herpes virus, cytomegalovirus, Epstein-Barr virus, hepatitis $B$ virus, and toxoplasma were present. There was no evidence of opportunistic infection at the time of the study but the patient is being investigated for interstitial pneumonitis and lymphocytic meningitis.

\section{Methods}

ULTRASTRUCTURAL IMMUNO-GOLD STAINING Postembedding method

Peripheral mononuclear cells isolated by Ficoll gradient were directly fixed by $2 \%$ glutaraldehyde in $0.1 \mathrm{M}$ cacodylate buffer, $\mathrm{pH} 7 \cdot 4$, for $2 \mathrm{~h}$ at room temperature. No postfixation was performed. The material was embedded in Epon as previously described. ${ }^{4}$ Ultrathin sections on nickel grids were first incubated with normal goat serum diluted 1/10 with Tris $\mathrm{NaCl}$ bovine serum albumin buffer, $\mathrm{pH}$ 
Table 1 Immuno-gold reactions of patient's lymphocytes

\begin{tabular}{|c|c|c|c|}
\hline \multicolumn{2}{|c|}{ Anti-bovine leukaemia virus antibodies } & \multicolumn{2}{|l|}{ Anti-human $T$ cell leukaemia virus 1 antibodies } \\
\hline $\begin{array}{l}\text { Polyclonal anti p-24 } \\
\text { Polyclonal anti gp51 } \\
\text { Monoclonal anti-p-24 } \\
\text { (4'F5) }\end{array}$ & $\begin{array}{l}+ \\
+ \\
+\end{array}$ & $\begin{array}{l}\text { Polyclonal anti-p-24 } \\
\text { Monoclonal anti-p-24 } \\
\text { Monoclonal anti-p-19 }\end{array}$ & $\begin{array}{l} \pm \\
-\end{array}$ \\
\hline \multicolumn{2}{|c|}{ Other anti-retrovinus antibodies } & \multicolumn{2}{|l|}{ Control antibodies } \\
\hline $\begin{array}{l}\text { Polyclonal anti-p-30 } \\
\text { (Rauscher) } \\
\text { Polyclonal anti-gp70 } \\
\text { (Rauscher) } \\
\text { Polyclonal anti-avian } \\
\text { myeloblastosis virus }\end{array}$ & $\begin{array}{l} \pm \\
- \\
-\end{array}$ & $\begin{array}{l}\text { Normal R S } \\
\text { Rabbit anti-legumin } \\
\text { Monoclonal (control) } \\
\text { Goat antirabbit gold alone } \\
\text { Anti-p } 24 \text { (BLV) depleted by the corresponding antigen }\end{array}$ & $\begin{array}{l}- \\
- \\
- \\
-\end{array}$ \\
\hline
\end{tabular}

$+=$ positive staining, $-=$ negative staining.

*A storage protein of plant origin. Serum of a rabbit hyperimmunised against this antigen did not show any reaction.

$8 \cdot 2$; then with antiretrovirus antiserum (Table 1 ) diluted $1 / 1000$ in the same buffer; and finally with the corresponding immuno-gold conjugate: goat antirabbit gold $5 \mathrm{~nm}$, goat antimouse gold $5 \mathrm{~nm}$, or rabbit antigoat gold $5 \mathrm{~nm}$ (obtained from Janssen Life Sciences Products, Beerse, Belgium).

\section{Incubation of living cells}

The mononuclear cells collected in RPMI were first incubated with the antiretrovirus serum diluted in phosphate buffered saline, $1 \%$ human $A B$ serum, $0.2 \%$ azide sucrose free medium, and then incubated in the immuno-gold conjugate.

Finally, the material was fixed in $4 \%$ glutaraldehyde in Millonig buffer and postfixed with $2 \%$ $\mathrm{OSO}_{4}$ before embedding in Epon.

\section{Controls}

Lymphocytes from the patient were tested with normal rabbit serum, polyclonal antilegumin rabbit serum, control monoclonal antiserum, and goat antirabbit gold alone. The specificity of the rabbit polyclonal anti-p24 bovine leukaemia virus antiserum was evaluated after depletion with lysed bovine leukaemia virus particles. Immuno-gold staining was also performed on the peripheral lymphocytes from a normal woman and from a man with active hepatitis $B$ virus infection.

Bovine leukaemia virus antibodies were tested with the same postembedding technique on fetal lamb kidney cells producing bovine leukaemia virus and on centrifuged bovine leukaemia virus particles from the Laboratory of Virology, Institute of Molecular Biology, (A Burny). On the other hand, human $T$ cell leukaemia virus antibodies were tested on virus producing cells issued from the laboratory of RC Gallo.

SEPARATION OF THE DIFFERENT POPULATIONS

OF MONONUCLEAR CELLS

Fresh peripheral blood mononuclear cells were iso- lated by Ficoll-Hypaque gradient. These cells were further fractionated by the formation of sheep red blood cell rosettes. The resulting $\mathrm{T}$ cell population was depleted in $\mathrm{OKT} 4^{+}$cells by treatment with the corresponding cytotoxic monoclonal antibody in the presence of complement. ${ }^{5}$ The isolation of OKT4 $4^{+}$ cells for ultrastructural study was not possible because of their reduced number.

\section{BOVINE LEUKAEMIA VIRUS SEROLOGY}

Detection of bovine leukaemia virus p- 24 cross reacting antibodies was performed by the ELISA method. In this assay, Microtest plates (Gibco 2-69620) were coated with $100 \mathrm{ng}$ of purified bovine leukaemia virus $\mathrm{p}-24$ protein dissolved in $0.01 \mathrm{M} \mathrm{NaHCO}-\mathrm{Na}_{2} \mathrm{CO}_{3}, \mathrm{pH} \mathrm{9.6}$, buffer and then saturated with bovine serum albumin. They were then incubated with dilutions of serum samples. After washing, peroxidase conjugated protein A ( 10 ng) was added and its binding was revealed by $O$-phenylene diamine. Optical density readings obtained in the absence of serum dilutions were zero. A detailed description of the ELISA technique has been given elsewhere. ${ }^{6}$

\section{SPECIFICITY OF ANTI-BOVINE LEUKAEMIA \\ VIRUS SERA}

Purification of bovine leukaemia virus gp-51 and p-24 has been described by Bex et al.' The purified proteins were injected into rabbits in order to obtain monospecific polyclonal antisera. The specificities of these sera were shown by radioimmune precipitation and polyacrylamide gel analysis of the precipitated antigen. ${ }^{89}$

\section{Results}

ULTRASTRUCTURAL OBSERVATIONS

Tubuloreticular structures and numerous multivesicular bodies but no test tube or ring shaped forms were encountered in a few lymphocytes and 

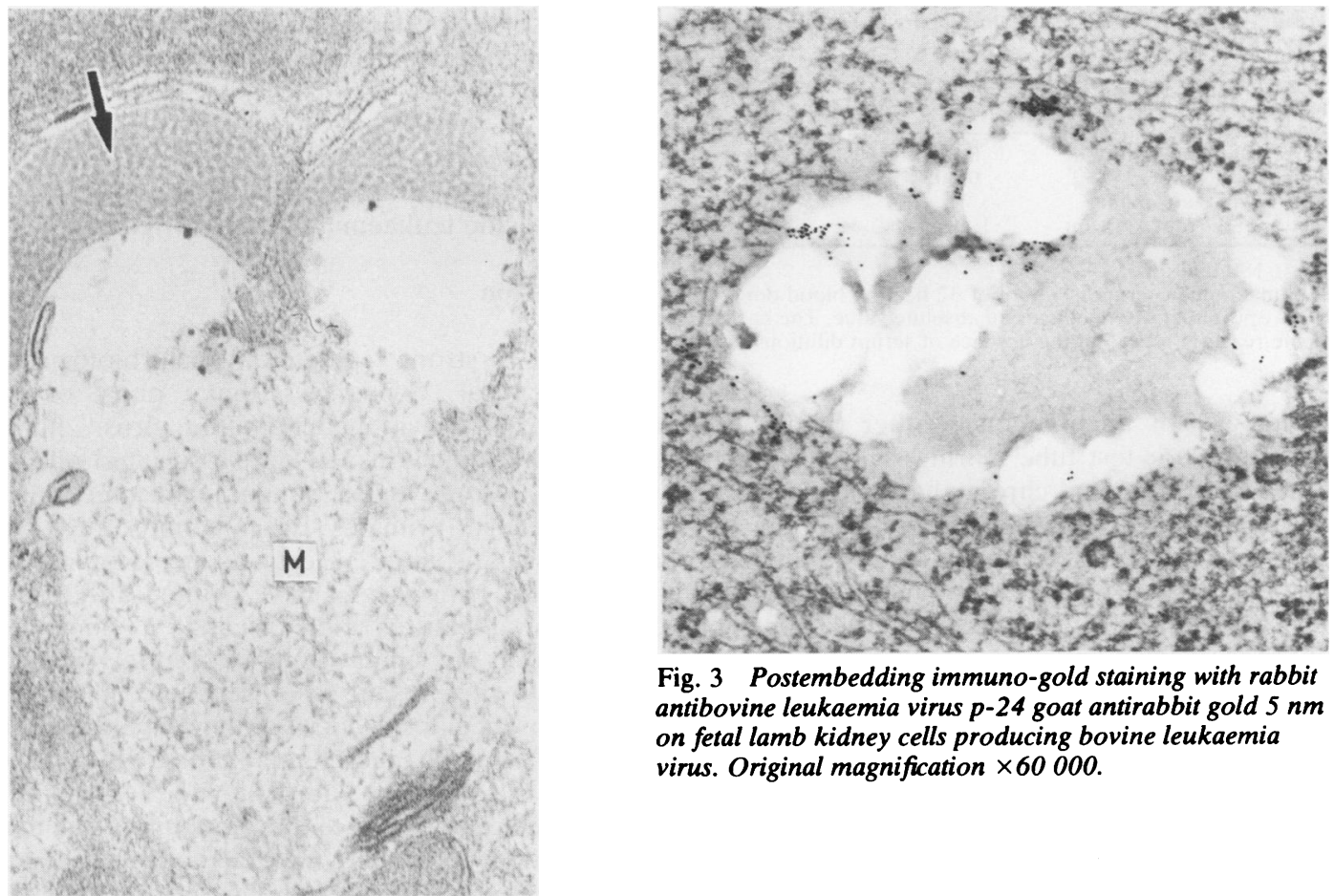

Fig. 3 Postembedding immuno-gold staining with rabbit antibovine leukaemia virus p-24 goat antirabbit gold $5 \mathrm{~nm}$ on fetal lamb kidney cells producing bovine leukaemia virus. Original magnification $\times 60000$.

Fig. 1 Patient's lymphocyte with giant multivesicular bodies $(M)$ and reticular inclusions (arrow). Original magnification $\times 60000$.

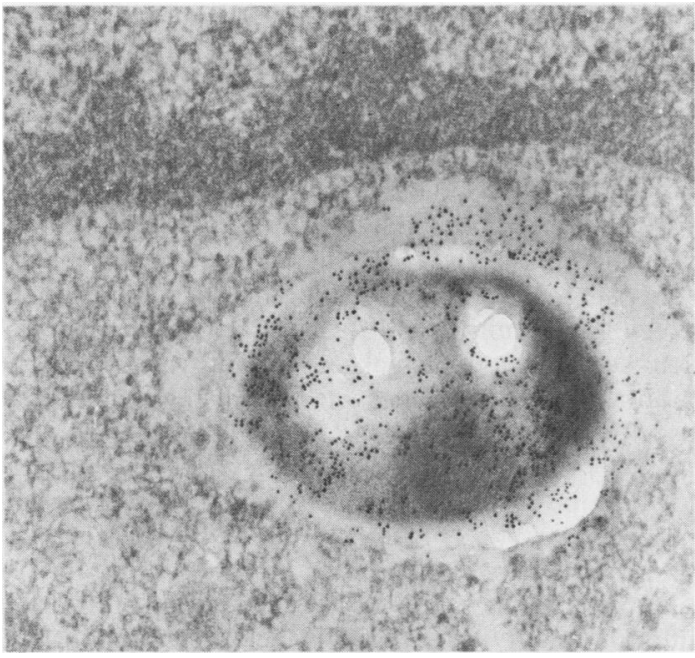

Fig. 2 Postembedding immuno-gold staining with rabbit antibovine leukaemia virus p-24 goat antirabbit gold $5 \mathrm{~nm}$ on patient's lymphocyte. Original magnification $\times 60000$. 
Table 2 Anti-bovine leukaemia virus reactivity in patient's seruin

\begin{tabular}{lc}
\hline Serum sample* & Optical density $(492 \mathrm{~nm})^{+}$ \\
\hline Normal human serum $\dagger$ & $0.016 \ddagger$ \\
Patient s serum & 0.205 \\
Anti-bovine leukaemia & \\
virus p-24 rabbit serum & $>1.500$ \\
\hline
\end{tabular}

*At $1 / 180$ dilution.

†Normal human serum is a pool of 32 healthy blood donors. $\ddagger$ This optical density reading is an absolute value. The background of the reaction is zero in the absence of serum dilutions.

monocytes of the patient. Neither tubuloreticular structures nor test tube or ring shaped forms were found in normal and chronic hepatitis controls.

A striking feature was the presence of great cytoplasmic vacuoles resembling giant multivesicular bodies in about $1 \%$ of the mononuclear cells (Fig. 1). They contained a granular material, some double outlined vesicles, and were often adjacent to " reticular" inclusions. In our experience, giant multivesicular bodies have been encountered in four prodromal cases of AIDS in black Africans. In the present case, such giant multivesicular bodies were not present either in the separate populations of suppressor cells $\left(\mathrm{OKT}^{+}\right.$cells $)$nor in B cells and monocytes. Postembedding immuno-gold staining performed with rabbit anti-bovine leukaemia virus p-24, rabbit anti-bovine leukaemia virus gp-51 polyclonal antibodies, and goat anti-human $\mathrm{T}$ cell leukaemia virus $\mathrm{I}$ p-24 polyclonal antibody was strongly positive in the giant multivesicular bodies (Fig. 2). No staining was observed with antiavian myeloblastosis virus polyclonal antibody and monoclonal antibodies against bovine leukaemia virus and human $\mathrm{T}$ cell leukaemia virus I. Anti-Rauscher virus p-30 polyclonal antibody gave a weak staining reaction (Table 1). There was no staining at the level of the tubuloreticular structures. In the $\mathrm{OKT}^{+}$cells, B lymphocytes, and monocytes, no staining was observed. No staining was detected with control rabbit, mouse, or goatantirabbit gold antibodies. Moreover, the staining with anti-bovine leukaemia virus p-24 antibody was suppressed after depletion with the corresponding antigen. The staining of the fetal lamb kidney cells producing bovine leukaemia virus with anti-bovine leukaemia virus antibodies (Fig. 3) was positive in the cytoplasmic inclusions. A specific staining with a minimal background of the human $T$ cell leukaemia virus producing cells with anti-human $T$ cell leukaemia virus I antibodies was also obtained.

Finally, staining was also observed at the level of the giant multivesicular bodies of living cells with the rabbit anti-p-24 bovine leukaemia virus polyclonal antibody (Fig. 4). This reaction was still present after incubation with sodium azide and in sucrose free buffers. During the development of the disease intracytoplasmic stained inclusions disappeared.

\section{SEROLOGICAL OBSERVATIONS}

As shown in Table 2, the patient's serum contained anti-bovine leukaemia virus $\mathrm{p}-24$ reactivity.

\section{Discussion}

There is strong epidemiological, biological, and biochemical evidence that one or more retroviruses-lymphadenopathic virus,' human T cell leukaemia virus III $^{2}$ - are associated with human AIDS. Moreover, a similar syndrome has been induced in primates by injection of a type $D$ retrovirus isolate. ${ }^{10}$ Electron microscopical studies of AIDS lymphocytes have defined different ultrastructural features of the disease. ${ }^{11-17}$ Some of these structures are similar to those seen in virus infected cells. In the present case, we found, in addition to tubuloreticular structures and multivesicular bodies, cytoplasmic changes reminiscent of those encountered in fetal lamb kidney-bovine leukaemia virus infected cells. We were therefore interested in investigating whether bovine leukaemia virus related antigens could be shown at the ultrastructural level. For this purpose, we used an immuno-gold staininge technique that has already been applied to the intracellular identification of viral antigens. ${ }^{\text {is }}$ The $\rightleftharpoons$ validity of this staining method for the detection of human $T$ cell leukaemia virus $I$ and bovine leukaemia virus antigens was confirmed in preliminary experiments involving virus producing cells. The use of glutaraldehyde alone as a fixative allows a satisfactory conservation of the ultrastructure without altering the specificity of antigen-antibody reactions.

In our patient we noted a specific reactivity with polyclonal antibodies directed against the major core protein of bovine leukaemia virus and human $\mathrm{T}$ cell leukaemia virus $\mathrm{I}$. This cross reactivity is not surprising since bovine leukaemia virus and human $T$ cell leukaemia virus I $\mathrm{p}-24 \mathrm{~s}$ share common amino acid sequences. The lack of staining with the tested monoclonal antibodies is consistent with the hypothesis that the detected antigen belongs to a member of the bovine leukaemia virus-human $T$ cell leukaemia virus family. A positive immuno-gold reaction was also present in unfixed cells incubated under conditions ensuring inhibition of pinocytosis of the $5 \mathrm{~nm}$ gold particles. The transient immunoreactivity of patient's cells is consistent with the findings of Popovic et al, ${ }^{2}$ who reported transient expression of cytopathic variants of human $T$ cell leukaemia virus III in celts of patients with AIDS. 
The presence of a positive bovine leukaemia virus serology further suggests that our patient has been in contact with a related virus.

Obviously, the importance of our findings obtained in a single case is difficult to assess and similar studies on other patients at different stages of the syndrome are needed to investigate the possible relation between the antigens found in the present case and the putative agent(s) of AIDS.

We thank Dr RC Gallo for providing human $\mathrm{T}$ cell leukaemia virus I reagents and Dr S Izui for providing anti-Rauscher virus antibodies. We are grateful to Dr J Sternon, who is taking care of the patient. We thank JL Conreur for technical assistance and $\mathbf{J}$ De Ligne for typing the manuscript. This work was supported by grants from the "Fondation Rose et Jean Hoguet."

\section{References}

' Vilmer E, Barre-Sinoussi F, Rouzioux C, et al. Isolation of new lymphotropic retrovirus from two siblings with haemophilia B, one with AIDS. Lancet 1984;i:753-7.

2 Popovic M, Sarngadharan MG, Read E, Gallo RC. Detection, isolation and continuous production of cytopathic retroviruses (HTLV-III) from patients with AIDS and pre-AIDS. Science 1984;224:497-500.

${ }^{3}$ De Mey J. Immunocytochemistry-practical applications in pathology and biology, London: Wright, 1983;82-112.

${ }^{4}$ Feremans WW, Neve P, Caudron M. IgM lambda cytoplasmic crystals in three cases of immunocytoma: a clinical, cytochemical and ultrastructural study. J Clin Pathol 1978;31:250-8.

${ }^{5}$ Thomas Y, Sosman J, Irigoyen $\mathrm{O}$, et al. Functional analysis of human T-cell subsets defined by monoclonal antibodies. $J$
Immunol 1980; 125:2402-8.

- Portetelle D, Bruck C, Mammerickx M, Burny A. Use of monoclonal antibody in an Elisa test for the detection of antibodies to bovine leukaemia virus. J Virol Meth 1983;6:19-29.

${ }^{7}$ Bex F, Bruck C, Mammerickx M; et al. Humoral antibody response to bovine leukaemia virus infection in cattle and sheep. Cancer Res 1979;39:1118-23.

${ }^{8}$ Ghvsdael J. Kettmann R, Burny A. Translation of bovine leukaemia virus virian RNAs in heterologous proteinsynthesizing systems. $J$ Virol 1979; 29: 1087-98.

${ }^{*}$ Portetelle D, Bruck C, Mammerickx M, Burny A. In animals infected by bovine leukaemia virus (BLV) antibodies to envelope glycoprotein gp 51 are directed against the carbohydrate moiety. Virology 1980; 105:223-33.

${ }^{10}$ Marx PA, Maul DH, Osborn KG, et al. Simian AIDS: isolation of a type $D$ retrovirus and transmission of the disease. Science 1984;223: 1083-6.

"Sidhu G, Stahl RE, El-Sadr W, Zolla-Pazner S. Ultrastructural markers of AIDS. Lancet 1983;i:990-1.

'2 Schaff Z, Tabor E, Jackson DR, Gerety RJ. AIDS-associated ultrastructural changes. Lancet $1983 ;$ i: 1336.

${ }^{13}$ Feremans WW, Menu R, Dustin P, Clumeck N, Marcelis L, Hupin J. Virus-like particles in lymphocytes of seven cases of AIDS in black Africans. Lancet 1983;ij:52-3.

14 Orenstein JM. Ultrastructural markers in AIDS. Lancet 1983;ii:284-5.

is Sidhu G. Ultrastructure of AIDS lymph nodes. $N$ Engl J Med 1983;309: 1188-9.

${ }^{16}$ Miller SE, Rogers JF. Ultrastructure of AIDS lymph nodes. $N$ Engl J Med 1983; 309:1189-90.

17 Anderson MG, Dixey J, Key P, et al. Persistent lymphadenopathy in homosexual men: A clinical and ultrastructural study. Lancet 1984; i:880-2.

${ }^{18}$ Garzon S, Bendayan M, Kurstak E. Ultrastructural localization of viral antigens using the protein A-gold technique. J Virol Meth 1982;5:67-73.

Requests for reprints to: Dr W Feremans, Laboratory of Pathology and Electron Microscopy, Université Libre de Bruxelles, Route de Lennik 808, B-1070 Bruxelles, Belgium. 